\title{
Flotation of copper-bearing shale in solutions of inorganic salts and organic reagents
}

\author{
Tomasz Ratajczak ${ }^{1 * *}$ \\ ${ }^{1}$ Wroclaw University of Science and Technology, Faculty of Geoengineering, Mining and Geology, Wybrzeze Wyspianskiego 27, \\ 50-370 Wroclaw
}

\begin{abstract}
Flotation data on copper-bearing shale in aqueous solutions of inorganic electrolytes $(\mathrm{NaCl}$, $\mathrm{Na}_{2} \mathrm{SO}_{4}, \mathrm{KPF}_{6}, \mathrm{NH}_{4} \mathrm{Cl}$ ) and organic reagents (ethylamine, propylamine) as frothers were presented and discussed . The relationships between shale flotation, surface tension of aqueous solution and foam height during bubbling with air in the flotation system were presented. It has been found that flotation of shale in the presence of inorganic salts the yield was directly proportional to the surface tension of the aqueous solution of salt and inversely proportional to the height of the foam. On the other hand, for organic reagents solutions (short chain amines), a reverse effect has been observed in relation to the inorganic compounds studied, that is the yield of copper-bearing shale flotation and the foam height were inversely proportional to the surface tension of the amine solution.
\end{abstract}

\section{Introduction}

Salt flotation relies on flotation in saline solutions [1, 2] without the presence of additional reagents. Salt flotation mechanism and results depend on the type, concentration and foaming properties of the saline solutions. Inorganic salts can replace organic frothers in flotation but not all inorganic salts are good frothers [1, 2, 3, 4, 5, 6, 7]. From these works it can be seen that the salts that raise or lower the surface tension can cause, respectively, an increase or decrease of flotation of naturally hydrophobic minerals. The aim of this works, which is based on flotation results of Smolska and Ratajczak [6] and Witan and Ratajczak [7], was to compare the influence of inorganic and organic regents on flotation of naturally hydrophobic copperbearing shale and to determine how the flotation results depend on foaming and surface tension of these regents in aqueous solutions.

\section{Flotation of copper-bearing shale in solutions of inorganic electrolytes}

Flotation of copper-bearing shale, denoted by Drzymala et al. [8], as shale $\mathrm{P}$, was carried out using a mono-bubble type Hallimond cell with a capacity of $200 \mathrm{~cm}^{3}$ and height of $36 \mathrm{~cm}$. The investigations were carried out in distilled water and in the presence of aqueous solutions of $\mathrm{NaCl}$, $\mathrm{Na}_{2} \mathrm{SO}_{4}$ at concentrations of 0.5 to $2 \mathrm{~mol} / \mathrm{dm}^{3}$ and $\mathrm{KPF}_{6}$ at concentrations of 0.05 to $0.25 \mathrm{~mol} / \mathrm{dm}^{3}$, that is up to its solubility limit. More precise description of methodology of investigations is given in the works of Smolska and Ratajczak [6] and Smolska [9].

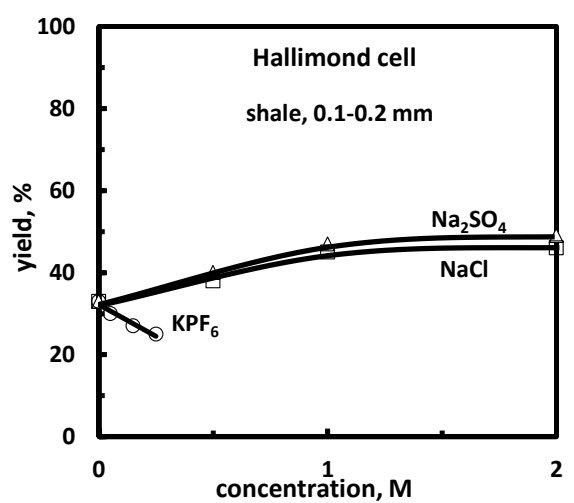

a)

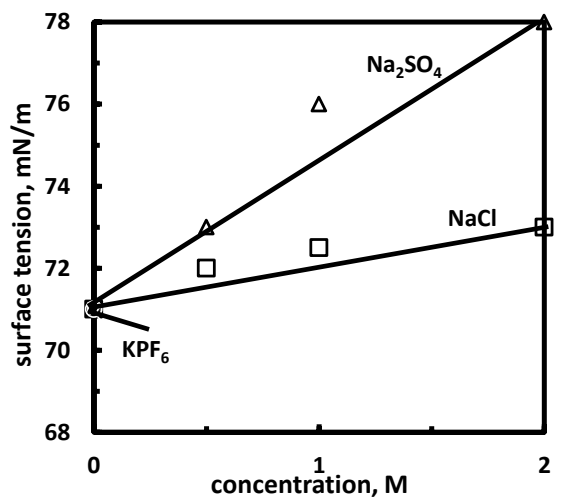

b)

\footnotetext{
* Corresponding author: tomasz.ratajczak@pwr.edu.p1
} 


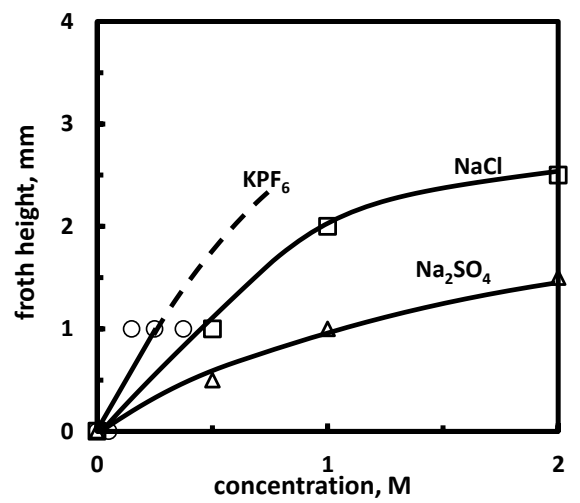

c)

Fig. 1. Dependence of a) yield of flotation of copper-bearing shale [6], b) surface tension [6]; [2]; [10]; [11], c) foam height [6] on the concentration of the investigated salt solutions.

Smolska [9] investigated flotation and the height of foam during air bubbling through water containing salts that have different surface tension of aqueous solutions (Figure 1). Figure 1a shows that flotation yield decreases in the presence of KPF6 and increases in the Na2SO4 and $\mathrm{NaCl}$ aqueous solutions. A comparison of yield with foam height and surface tension indicates that the yield increases in the same manner as surface tension and decreases with foam height.

\section{Flotation of copper-bearing shale in solutions of organic reagents}

To determine the influence of organic regents on flotation, the tests were carried out in a Mechanobr flotation machine equipped with a $0.25 \mathrm{dm}^{3}$ flotation cell. Reagents used for testing were ammonium chloride, as the first member of the normal short chain amines family and ethylamine as well as propylamine. For each flotation 30 $\mathrm{g}$ of $-100 \mu \mathrm{m}$ in sizw copper-bearing shale $\mathrm{P}$ was used. The time of flotation was $30 \mathrm{~min}$. More details on methodology of flotation is given in the work of Witan and Ratajczak [7] and Witan [12].

Figure $2 \mathrm{a}$ shows the effect of concentration of ammonium chloride, ethylamine and propylamine on the yield of copper-bearing shale after 15 minutes of flotation. Figure $2 \mathrm{~b}$ show the influence of concentration of the used frother surface tension change $(\Delta \gamma)$ in relation to pure water while Fig. 2c the froth height. According to Fig. 2a, ammonium chloride makes the yield of shale slightly decreasing with a small rise in the froth height (Fig. 2c), while the surface tension increases (Fig. 2b). This agrees with the data obtained for inorganic salts show in Fig.1. On the other hand, for ethylamine and propylamine, for which the surface tension decreases with increasing concentration of frother (Figure 2b), a slight increase in yield is observed with increasing height of flotation froth (Figure 2c).

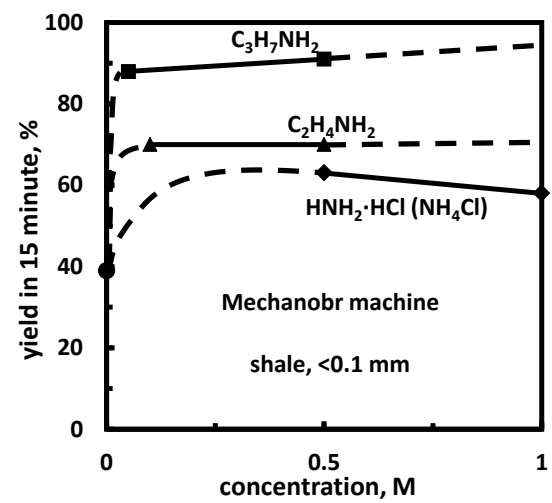

a)

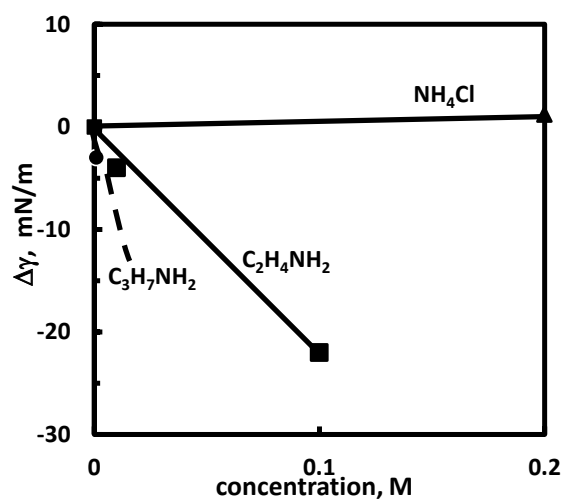

b)

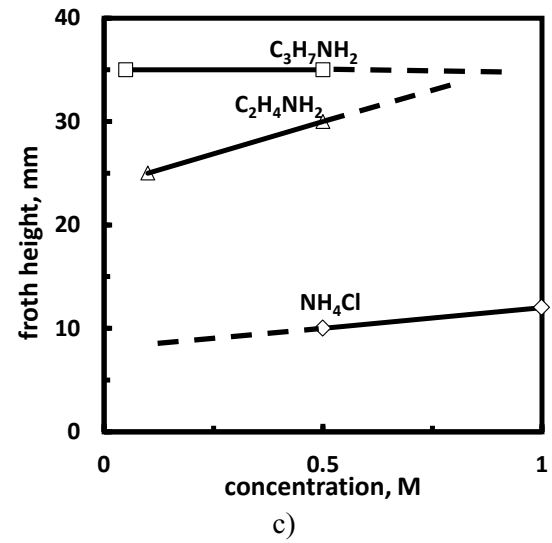

Fig. 2. Effect of concentration of ammonium chloride, ethylamine and propylamine on a) yield of copper-bearing shale after 15 minutes of flotation [7], b) surface tension of their solutions [13 (for $\mathrm{NH}_{4} \mathrm{Cl}$, at $25{ }^{\circ} \mathrm{C}$ ); 14 (for $\mathrm{C}_{2} \mathrm{H}_{4} \mathrm{NH}_{2}$ at $30{ }^{\circ} \mathrm{C}$, 15 (for $\mathrm{C}_{3} \mathrm{H}_{7} \mathrm{NH}_{2}$, at $25^{\circ} \mathrm{C}$ ), c) froth height after 5 minutes of shale flotation) [7].

\section{Summary}

The results of the studies confirm influence of inorganic and organic reagents on flotation of copper-bearing shale. It was found that in the case of increasing concentrations of $\mathrm{NaCl}$ and $\mathrm{Na}_{2} \mathrm{SO}_{4}$, shale yield increases while for $\mathrm{KPF}_{6}$ it decreases. Thus, it is shown that the yield of salt flotation of shale depends on the concentration and type of salt. It increases with increasing surface tension of salt and decreases as surface tension of salt solution decreases. However, the foaming of the salt solution increases with lower surface tension of the salt, that is, as in the case of 
organic frothers. Thus, the flotation of the shale in solutions of inorganic salts depends on the concentration, type of salt and foaming, and in turn on the surface tension of the salt.

Ammonium chloride behaves the same way as $\mathrm{NaCl}$ and other inorganic salts which increase surface tension. However, in the relations between yield, surface tension and froth height are different foe organic reagents. Ethylamine and propylamine, for which the surface tension decreases with increasing concentration, make flotation better while froth height increases.

In addition, it can be noticed from Fig. 2 that the maximum yield of the flotation froth product in the presence of propylamine is higher than that in salmiac and ethylamine, indicating increasing collecting properties of amine with the increasing length of the hydrocarbon radical.

This work was financed by the Polish Statutory Research Grant 0401/0124/2016.

\section{References}

1. J. Laskowski, J. Colliery Guardian, 211, 361-366, (1965)

2. T. Ratajczak, J. Drzymała, Flotacja solna (Oficyna Wydawnicza Politechniki Wrocławskiej, Wrocław, 2003)

3. R. J. Pugh, P. Weissenborn, O. Paulson, Int. J. Miner. Process., 51, 125-138, (1997)

4. B. Grabowski, J. Drzymała, Annales UMCS Sectio AA, LXIII, 6, 68-72, (2008)

5. M. Lipniarski, T. Ratajczak, J. Drzymała, Weryfikacja hipotez o roli soli we flotacji na przykładzie węla kamiennego $w$ wodnych roztworach $\mathrm{NaCl} i \mathrm{KPF}_{6}$, (III Polski Kongres Górniczy, Mineralurgia i wykorzystanie surowców mineralnych, Drzymała J., Kowalczuk P.B. (red.),
14-16 września 2015, Wrocław, WGGG PWr, 35-39, 2015)

6. M. Smólska, T. Ratajczak, Flotacja solna tupka miedzionośnego we flotowniku Hallimonda (WGGG PWr, Wrocław, 2017)

7. J. Witan, T. Ratajczak, Stabilność piany flotacyjnej $w$ obecności soli (WGGG PWr, Wrocław, 2017)

8. J. Drzymała, P. Karwowski, K. Borowski, P. Pązik, P.B. Kowalczuk, Próba klasyfikacji tupków Legnicko-Głogowskiego Okręgu Miedziowego na podstawie zawartości węglanów, minerałów ilastych, węgla organicznego oraz miedzi, (in: Łupek miedzionośny III, Kowalczuk P.B., Drzymała J. (red.), WGGG PWr, Wrocław, 2017, doi: 10.5277/lupek1702, 2017)

9. M. Smólska, Flotacja solna tupka miedzionośnego we flotowniku Hallimonda. Praca dyplomowa, opiekun T. Ratajczak (WGGG PWr, Wrocław, praca niepublikowana, 2017)

10. J. Lyklema, Fundamentals of interface and colloid science., Vol. 2, Fundamentals, (Academic Press, London, 1995)

11. L. Ghosh, K.P. Das, D.K. Chattoraj, J. Coll. Int. Sci., 121, 1, 278-288, (1988)

12. J. Witan, Stabilność piany flotacyjnej $w$ obecności soli. Praca dyplomowa, opiekun T. Ratajczak, (WGGG Politechniki Wrocławskiej, Wrocław, praca niepublikowana, 2017)

13. J. Lyklema, Fundamentals of interface and colloid science. Vol. 3, Liquid-fluid interfaces (Academic Press, London, 2000)

14. J. He, H. Liu, P. Shan, K. Zhang, Y. Qin, L. Liu, Chem. Eng. Sci., 141, 330-341, (2016)

15. B. J. George, N. Pereira, M. A. Massum, S. D. Kolev, M. Ashokkumar, Ultrason. Sonochem., 15, 151-156, (2008) 